Sobolieva, O. V. 2017a. Interpretatsiia roboty v «poli» u profesiinii diialnosti ukrainskykh zoolohiv. [Interpretation of «Field» Researches in the Professional Work of Ukrainian Zoologists]. Storinky istorii. Vyp. 43. 108-119. [in Ukrainian]

Sobolieva, O. 2017b. Khodyty v pryrodu: profesiina identychnist ta doslidnytski praktyky v ukrainskii polovii zoolohii. [Going to the Nature: the Professional Identity and Research Practices in Ukrainian Field Zoology]. Pole: zbirnyk naukovykh prats z istorii, teorii ta metodolohii polovykh doslidzhen, T. 2. Subkultury. Povsiakdennia. Etnohrafiia nauky. S. 39-74. [in Ukrainian]

Shnirelman, V. A. 2015. Pochemu nauchnye revolyutsii obkhodyat nas storonoy? [Why do Scientific Revolutions Pass us By?]. Antropologicheskiy forum, № 24. S. 82-89. [in Russian]

Shchepanskaya, T. B. 2005a. Ekspeditsionnye traditsii: k topografii «polya» v neformalnom diskurse polevykh issledovateley (etnografov, arkheologov, antropologov). [Expeditionary Traditions: to the Topography of a «Field» in Informal Discourse of Field Researchers (Ethnographers, Archaeologists, Anthropologists)]. Problemy istoricheskogo regionovedeniya. Sbornik nauchnykh statey. St. Petersburg. S. 76-100. [in Russian]

Shchepanskaya, T. B. 2005b. Konstruktsii gendera v neformalnom diskurse professiy. [Constructs of Gender in Informal Discourse of Professions]. Antropologiya professiy. Saratov. S. 50-100. [in Russian]

Frank, R. D. \& Yakel, E. \& Faniel, I. M. 2015. Destruction / Reconstruction: Preservation of Archaeological and Zoological Research Data. Archival Science. V. 15. P. 141-167.

УДК 929(477)(092)

DOI: $10.20535 / 2307-5244.52 .2021 .236170$

I. I. Стамбол
ORCID: 0000-0002-3099-3862
Київський університет імені Бориса Грінченка,
I. Stambol
Kyiv Boris Grinchenko University

\title{
ТЕНДЕНЦӤ РОЗВИТКУ НОВІТНЬОЇ ПОЛЬСЬКОЇ БІОГРАФІСТИКИ (ЗА МАТЕРІАЛАМИ ВИДАННЯ «POLISH BIOGRAPHICAL STUDIES»)
}

\section{The trends of Development of Modern Polish Biography (on the Case Study of «Polish Biographical Studies»)}

Визначено основні тенденції розвитку біографічних досліджень у Польщуі на початку XXI cm. За основу взято публікації наукового журналу «Роlish Biographical Studies», щ⿻о виходить у Щецині з 2015 р. при Центрі біографічних досліджень. Серед проблем, які порушують польські науковиі, найпомітнішими є біографї̈ комуністичних функціонерів, військових та науковців різних галузей. Окрім того, дослідження стосуються постколоніального наративу в біографічних текстах і гендерних питань. 
Ключові слова: біографістика, науковці, політичні діячі, польська гуманітаристика, «Polish Biographical Studies», XXI ст.

In the article, we determined the main tendencies of the development of biography in Poland in the early 2000's. In our research, we based on the publication of the scientific journal «Polish Biographical Studies», published in Szczecin since 2015 at the Center for Biographical Studies. The main problems raised by Polish researchers concern the biographies of Polish communists, the military, the multidisciplinary nature of biography, and the division of humanities into periods. Articles contained in the publication are divided into groups by topic, including political, intellectual, collective, female, and separately Jewish biographies. Also, we noted publications of biographical documents.

It has been found that Polish biographers are mostly interested in the period of the first two thirds of the twentieth century. In particular, they focus on biographies of thinkers of the Second Rzeczpospolita, educators, and politicians. In our study, we noted the discourse on fighting in the anti-German and anti-Soviet underground. Participation in the church and student organizations, as well as acquaintance with figures like Jozef Pilsudski or Roman Dmowski are very common in political biographies. With no exception for Jewish biographies, where most of the people mentioned as heroes of the uprising and underground movements in the ghetto. Even though they went to Palestine, they remain «Polish» in biographical discourse. Also in "Polish Biographical Studies», most biographies also tend to be political and they "supersede" biographies of engineers, athletes, or artists.

Comparing the Polish biographical publication with the "Ukrainian Biography» in 2013-2017, Ukrainians published almost twice as many theoretical works and biographies of scientists. It included more political and collective biographies and the same number of source articles. At the same time, there are more female biographies in the Polish edition, as well as biographies of Jews, while none in the Ukrainian. This explains that biographies of Polish Jews are perceived as the property of Polish society by Polish scholars when such identification almost does not in Ukraine.

Keywords: biography, scientists, political figures, Polish humanities, Polish Biographical Studies, Ukrainian biography 21 st cent.

Біографічні студії часто розвиваються за спільними закономірностями, але, водночас, якісно відрізняються, якщо порівнювати різні національні наративи. Особливо цікавим для вітчизняної науки є досвід сусідів, зокрема польських дослідників, які, хоч і мають низку посттоталітарних проблем, але значно більше просунулися в контексті західних постмодерних практик порівняно з українцями. Значним виразником тенденцій польської біогра- 
фістики є «Polish Biographical Studies», який започаткували у Щецині 2015 p. дослідники Центру біографічних досліджень місцевого університету. Аналіз праць, уміщених у даному виданні, дає можливість визначити головні теоретичні проблеми й напрями людинознавчих питань, які порушують польські науковці в останні роки (Стамбол, I. 2019).

Питання тенденцій польської біографіки частково порушувалося в українських досліженнях, зокрема в статтях В. Тимченка, який з'ясував особливості традиції «Польського біографічного словника» (Тимченко, В. 2008). Також загальну картину польської біографістики в українському виданні було охарактеризовано в дослідженні К. Грисінської-Ярмули, яка лише оглядово розглянула найновітніший період (Grysińska-Jarmuła, K. 2016). В той самий час у Польщі біографічним дослідженням присвячено багато робіт, зокрема монографій, зокрема важливим є одне з останніх монографічних видань «Biografistyka we współczesnych badaniach historycznych», що вийшло 2017 p.

Водночас статті видання «Polish Biographical Studies» раніше було проаналізовано лише частково (Стамбол, I. 2019). Тому дослідження їхньої тематики та методики є актуальним. Отже, мета даної статті - визначити основні тенденції біографістики в розвідках, уміщених на сторінках вказаного видання, завданнями - з'ясувати тематику статей, методичні підходи, професійний склад досліджуваних постатей та період, якому надають перевагу дослідники, а також провести паралелі з сучасними українськими біографічними студіями.

За тематикою статті, вміщені в «Polish Biographical Studies», можна поділити на кілька груп. Одну з найважливіших груп, що стосується теоретичних праць з біографістики, було охарактеризовано раніше (Стамбол, I. 2019). Тому розглянемо іiї особливості в загальних рисах. Зокрема, Тереза Репа розглянула біографії як психо-фізіологічне явище й визначила, що історична біографія - це лише третій етап з'ясування життєвого шляху людини. Перші два - це аналіз фізіолога-медика, а далі - психолога (Rzepa, T. 2013.). Кароль Олейник теоретизував у напрямі військової біографії, поділивши джерела на ті, що стосуються мирного і воєнного часу. Він відзначив, що такі джерела часто є лише офіційними і щодо рядового складу важко знайти документи особового походження чи мемуари. Окрім того, К. Олейник пояснив місце війни у біографіях військових діячів: вона є складним і часто суб'єктивно оцінюваним процесом, і переважно включає ідеологічну складову (Olejnik, K. 2013, s. 27-30).

В контексті проблем біографії людини часів Польської народної республіки (PRL) Е. Красуцький простежив полеміку істориків тієї доби навколо біографістики та виокремив поділ біографіки на «чисту» (де предметом дослідження $є$ людина) та «претекстову» (де герой $є$ вмонтованим в історичні обставини), який запропонував Т. Лепковський. Ще один постулат цьо- 
го теоретика, озвучений 1975 р., полягає в тому, що біографістика має бути інтердисциплінарною, поєднувати науку й мистецтво, психологію та історію культури й ментальності, як і біологію та медицину (Krasucki, E. 2014). Цікавою є теза М. Дроздовського, що наділяв біографістику функцією долання конфлікту між особистістю й суспільством (Drozdowski, M. 2014).

Є. Ейслер у праці з провокативною назвою «Чому ми не любимо біографій, що стосуються осіб з часів ПНР?» відзначив, що серед причин малої кількості досліджень є складність вивчення життя людей, які пережили кілька епох, особливо для двадцятирічних докторантів. Також - переконання багатьох істориків, що немає потреби досліджувати «безсенсовну» сьогодні «партійну» діяльність, на відміну від сучасного національного дискурсу; бажання в суспільстві забути прибічників та все, що пов'язане 3 «робітничим рухом» до 1989 р. (Eisler, J. 2014).

М. Шумило охарактеризував можливі варіанти підбору джерел і методологію написання біографіï «комуніста» (Szumiło, M. 2014). С. Мадейський в огляді тенденцій літературної біографії кінця XX — початку XXI ст. запропонував кілька розподілів цього напряму: хронологічний (класична біографія - найстаріша, новіше - словники і ще далі сильветки); національні підходи до автобіографій (німецька теорія звертає увагу на пам'ять індивідуальну й колективну; англосакси — на риторичне і типологічне розуміння та ін); крім того, біографія поділяється на «як вид», «як випадкову ситуацію», «як текст культури» (Madejski, J. 2014). Також Є. Мадейський стверджує, що біографія зараз змінила орієнтацію до нового історизму, постколоніалізму, гендеру й наукова біографія має потужного конкурента, яким є 3MI (Madejski, J. 2014).

Політична біографіка розкривається в кількох статтях, зокрема Маріана Мрозка, присвяченій Євгеніушу Ромеру (Mroczko, M. 2013). Діяча зображено як гуманіста і патріота. Дві його основні іпостасі — географія й політика — вплинули на становлення польської державності. Відзначено, що Ромер мав свої погляди на формування території Польщі і не погоджувався з Ю. Пілсудським. На його думку, кордон мав формуватися за географічним, культурним та історичним принципами. Перебуваючи, разом iз Р. Дмовським на конференції у Парижі, створив картографічну комісію. Ії роль стала вирішальною в контексті дискусії про кордони Польщі. Також автор відзначив місце Є. Ромера у перемовинах поляків щодо Галичини з американцями.

В зазначений період досліджено політичні віхи біографії Яна Вацлава Махайського (Potkański, W. 2015). Він є одним з родоначальників польського анархізму, який отримав назву махаївщина. Я. Махайський, як відзначив автор, вже зі студентського періоду перебував у середовищі лівих, за що отримав трійку з поведінки в університеті. Мав контакти з провідни- 
ми політиками, зокрема Р. Дмовським. Орієнтувався в дописах на пролетарів, але критикував Маркса. Внаслідок антицарської риторики відбув заслання в Сибіру, де встиг створити свою анархістську секту. 1917 р. перейшов до Росії, аби реалізовувати ідею «великої революції», за що 1926 р. похований у Москві як «герой революції».

Суспільно-політична діяльність Адама Плешнара й Адама Б’єня пов'язана зі студентськими рухами Польщі. Так, Б'єнь іще юнаком брав участь у Варшавській битві, а 1928 р. став одним з організаторів «Союзу молоді Речі Посполитої» (Indraszczyk, А. 2013). Написав програму розвитку суспільства, де доводив, що необхідно змінити кордони Речі Посполитої. Також виступав за федералізацію Польщі - створення Ягеллонської унії. Плешнар формував власний світогляд у період німецької окупації - належав до руху дітей католицьких і зі становленням «соціалізму» потрапив під арешти в 1951 i 1960 pp. Відзначився також участю в Організації молодих демократів і створив iï осередок у Вроцлавському університеті (Tyszkiewicz, A. 2016).

Ще дві політичні біографії стосуються поляків, народжених на теритоpiї України: Леона Реутта і Жигмунта Березовського. Перший — досліджений як президент міста Дрогобич і секретар місцевої національної організації (Wątor, A. 2013). Другий, уродженець Білої Церкви, — як активний учасник польського руху в Києві. Також відзначено журналістську, громадсько-політичну та редакторську діяльність Березовського у «Політиці правовій» (Turek, W. 2013).

Наступна група досліджень - біографії науковців. Як і в Україні, науковці в польській історіографії часто досліджуються поряд з їхніми здобутками в політиці, (класичний приклад — біографія М. Грушевського (Шаповал, Ю. 2018)). В статті про Євгеніуша Квятковського - творця польської морської політики та доктрини унії Європи Центрально-Східної, висвітлено його геополітичні погляди, зокрема обгрунтування значення моря для Польщі та ідею вільного ринку (Drozdowski, M. 2014). За ініціативи Квятковського в Щецині відкрито господарську академію. Йому ж належить проект польського морського господарства. Ще один економіст, чию біографію вміщено в «Polish Biographical Studies» — Ян Пивоварчик. Автор з'ясував його участь у товаристві Християнської демократії, роль у становленні видання «Tygodnik powczesny», а також - теоретичні праці, що побудови і реалізації фашистської економіки (Łętocha, R. 2015).

Ян Бобринський, якого автор дослідження відзначив як консерватора, публіцист та ідеолог, що походив з родини творця історичної школи в Кракові. Відстоював ідею об'єктивізму в економіці - на противагу демагогії й некерованості. Інша ідея, котру він пропагував - господарчий фронт: пробудження приватної ініціативи. Виступав також за етатитизм і непорушність прав власності (Paczos, S. 2015). 
Поряд з економістами, до науковців можна віднести й біографії педагогів. Так, одне $з$ досліджень присвячене засновнику ліцею в Щецині Болеславу Садаю. Автор з'ясував походження і освіту педагога, зокрема, підкреслено факт його стажування у Франції. Під час війни його заарештували німці й утримували як заручника (Magiera, E. 2015). Інший педагог - Тадеуш Лапушанський - розробив власну систему навчання й виховання. Його основна ідея виховання має три засади: права вихованців, розвиток індивідуальних здібностей, заохочення до творчої праці. Автор відзначив походження педагога: народився у Львові й навчався у Кракові, а також - активну громадську діяльність під час навчання (Łętocha, R. 2016). Як своєрідне підтвердження педагогічного таланту Лапушанського автор статті навів статистику, за якою $63 \%$ його випускників вчасно завершили вищу школу, на противагу типовим для тодішніх реалій $20 \%$.

Колективні портрети - наступна окрема група досліджень, вони стосуються академічних корпорацій (зокрема «Патрія», «Арконія» та «Регія») й молодіжних післявоєнних рухів. Автори довели, що молодь активно шукала себе в науці, про що свідчать виявлені їхні публікації. 3'ясовано, що частина об'єднань молоді мала національно-католицьку спрямованість. Також досліджено кола, що утворились навколо видання «Академік», редактори якого друкували праці кількох напрямів: полоністичні, славістичні, лужицькі (Sikorski, T. 2013).

Певною мірою, до колективного портрету належить історіографічний нарис, що стосується праць, присвячених основним польським політичним мислителям 1918-1939 рр. Автор зробив висновок, що стан видань $€$ незадовільним, бо не вистачає праць, присвячених постатям «другого ешелону» (Sikorski, T. 2013). Також помітні дослідження щодо польських генералів і дипломатів, а також підприємців, які протидіяли націоналізації й змушені були емігрувати (Turek, W. 2015). Окремо варто відзначити історію трьох священиків-католиків, що працювали в приєднаних до Польщі землях із переважно протестантським населенням. Їх діяльність супроводжувалася утисками «соціалістичної» влади, їх навіть визнавали ворогами народу. Це тривало до перелому 1951 р., коли ситуація поліпшилася (Cichocka, M. 2016).

Наступну групу праць становить жіноча біографія: як колективна, так і життєписи окремих діячок. Серед колективних, досліджено Охотничу легію жінок - першу військову жіночу організацію в Польщі, створену у Львові, під час боротьби проти українців. Серед іiі організаторок були Олександра Загорська, Ванда Гетс, Марія Хоєрська, Галина Ковальська. У біографіях цих жінок, що характерно, відзначено і їхніх чоловіків та дітей. Частина діячок мали офіцерські звання. Авторка дослідження відзначила, що жіноча організація відновила активність під час Другої світової війни - організовувала посилки для підтримки фронту (Marcinkiewicz-Kaczmarczyk, A. 
2016). Інша досліджена жіноча організація - Національна жіноча організація, створена 1919 р. Авторка статті визначила колективний портрет лідерок організації, відзначивши релігійні й політичні аспекти післявоєнного часу (Mysiakowska-Muszyńska, J. 2017).

Окреме дослідження присвячене педагогу Яніні Соїньській, де вміщено спогади про неї колег і учнів (Król, J. 2015). А також - Ванді Полтавській - лікарці й приятельці Яна Павла II, авторці «Бескидської реколекції». Досліджено ії молоді роки, проведені в Любліні, відзначено переломний момент - розмову з Войтилою, після якої, вона і пішла за ним, зокрема до Ватикану (Wiertelak, P. 2016).

Документальні публікації, які також варто виокремити самостійною групою, стосуються переважно періоду протистояння з більшовизмом. Так, надруковано матеріали справи Леонарда Борковича - режисера, який зазнав репресій за знятий фільм. Причому серед причин його вироку були як економічні - велика зарплата акторам, так i, що, звісно, реальніше «політична шкода» (Rembacka, K. 2013). Також опубліковано документи членів Клубу католицької інтелігенції - організації, створеної 1956 р. Комуністи довго відмовляли Клубу в реєстрації, але зрештою дозволили (Siedziako, M. 2013).

Останньою групою статей, яку можна виділити в біографічному журналі, є єврейська біографія. Так, у дослідженні, присвяченому Якубу Ласкеру, відзначено історії роду діяча, та характеристика сіонізму до війни. Докладна розповідь про доступні й відсутні документи. Деталі операції «Берхарда» в Заксенгаузені з підробленням грошей союзників, у якій брав участь Ласкер (Konopczyńska-Tota, E. 2014). Магдалена Семчишин розмірковує над причинами виїзду євреїв. Важливе спостереження авторки - в тому, що виїзди з Польщі організували учасники підпілля з Варшави, Вільнюса і Рівного. Значну увагу присвячено і неоднозначному сприйняттю євреїв у Польщі, умовам конспіративної роботи тощо (Semczyszyn, M. 2014).

Біографія іншого єврея - Леона Рейха — другого серед найпопулярніших сіоністів у Польщі, тісно пов'язана з Україною. Він був членом сейму з 1923-1926 рр. Народився у Дрогобичі та під час навчання в університеті Яна Казимира у Львові створив товариство «Сіон». Вів полеміку про те, що таке народ, визначив, що головне - це спільність і терпіння. Як делегат від українців брав участь в австрійському парламенті. 1918 р. заарештований у Львові як заручник. Також Рейх брав участь у Паризькій конференції й очолював організацію Євреїв Східної Галичини. Виступав за автономію євреїв у регіоні та вимагав окремого міністра в уряді Польщі. Мав також своєрідний погляд на українське питання: «євреї виступають за українську державу, бо українці бідні на інтелігенцію і євреї матимуть кращі варіанти, ніж у Польщі» (Yasui, M. 2013). Він також виступив автором угоди між 
поляками і євреями на 42 пункти й вів полеміку з іншим відомим мислителем - Володимиром Жаботинським (Yasui, M. 2013).

На завершення цього огляду біографічних публікацій варто порівняти тенденції польської біографістики з українськими. Як репрезентант українських біографічних студій найліпше підходить спеціально орієнтоване видання «Українська біографістика», але варто відзначити, що його обсяг значно більший, тому кількісне співвідношення може бути лише умовним (Котлярова, Т. 2016). Тож, якщо порівняти польське й українське видання за вказані 2013-2017 pр., українці видали майже вдвічі більше теоретичних праць (6 до 11) та біографій науковців (8 до 16), з меншою різницею, але також більше політичних (9 до 13) та колективних біографій (11 до 16) і однакову кількість джерелознавчих статей (4 і 4). Водночас у польському виданні більше жіночих біографій (3 до 1), а також є три життєписи євреїв, тоді як в українському - жодного. Вочевидь, це пояснюється тим, що біографії польських євреїв польські дослідники сприймають як надбання польського суспільства, а в Україні такого ототожнення майже не виникає.

Польських біографістів найбільше цікавить період перших двох третин XX ст. Зокрема, біографії мислителів часів Другої Речі Посполитої, освітян і державних діячів. Помітним є дискурс, присвячений боротьбі в підпіллі. Якщо схематично віддзеркалити колективний політичний портрет, то часто спільними моментами політичних біографій є участь у церковних та студентських організаціях, а також знайомство діячів із Ю. Пілсудським чи Р. Дмовським. Єврейська біографія - не виняток. Більшість згаданих осіб - герої повстань і підпільних рухів у гетто, тому, хоча вони й вирушили до Палестини, в біографічному дискурсі їх лишають «своїми». За професійним складом у виданні «Polish Biographical Studies» більшість біографій також мають ухил до політичного контексту і вони «витісняють» біографії інженерів, спортсменів та митців.

Котлярова, Т. В. 2016. Вітчизняна біографіка, біографістика та біобібліографія в роки незалежності України. Дванадцяті Біографічні читання. Українська біографістика. Вип. 13. С. 286-298.

Стамбол, І. 2019. Теоретичні проблеми польської біографістики на сторінках видання «Polish Biographical Studies». Матеріали Міжнародної наукової конферениії «Бібліотека. Наука. комунікація: актуальні тенденції у цифрову епоху». Київ: НБУВ. URL: http://conference.nbuv.gov.ua/report/view/id/861

Тимченко, В. М. 2008. Порівняльна характеристика польської та австрійської біографічної довідкової літератури. Українська біографістика. Вип. 4. С. 297-305.

Шаповал Ю. І. 2018. Михайло Грушевський. «Я сам прийшов до політики через історію...». Київ: Парламентське вид-во.

Cichocka, M. 2016. Zdeterminowani. Fragmenty życiorysów trzech rządców Kurii Gorzowskiej (1945-1956). Polish Biographical Studies. № 4. S. 65-98. 
Drozdowski, M. 2014. Eugeniusz Kwiatkowski o Szczecinie i Pomorzu Zachodnim. Polish Biographical Studies. № 2. S. 131-146.

Eisler J. 2014. Dlaczego nie lubimy biografii dotyczących osób z czasów PRL? Polish Biographical Studies. № 2. S. 39-48.

Grysińska-Jarmuła, K. 2016. Tendencje rozwojowe polskiej biografistyki od konca XIX do poczatkow XXI wieku. Українська біографістика. Вип. 13. С. 51-74.

Indraszczyk, A. 2013 Adam Bień 1899-1998. Szkic biograficzny. Polish Biographical Studies. № 1. S. 177-190.

Konopczyńska-Tota, E. 2014. Filolog w archiwum. W poszukiwaniu źródeł do biografii Jakuba Laskiera. Polish Biographical Studies. № 2. S. 113-130.

Krasucki, E. 2014. Dyskusje polskich historyków (krajowych) wokół biografistyki między «odwilżą» a upadkiem PRL. Polish Biographical Studies. № 2. S. 11-39.

Król, J. 2015. Janina Parafiniuk-Soińska (1922-2012): szczecińska pedagog i uczona. Polish Biographical Studies. № 3. S. 143-158.

Łętocha, R. 2015. Fundamenty ideowe myśli społeczno-gospodarczej i politycznej ks. Jana Piwowarczyka. Polish Biographical Studies. № 3. S. 57-72

Łętocha, R. 2016. Tadeusz Łopuszański: pedagog, wychowawca, polityk. Polish Biographical Studies. № 4. S. 51-63.

Madejski, J. 2014. Portret, słownik, sylwa... Biografistyka (literacka) na przełomie XX i XXI wieku. Polish Biographical Studies. № 2. S. 77-92.

Magiera, E. 2015. Bolesław Wojciech Sadaj (1908-1997) jako twórca szczecińskiej pedagogiki. Polish Biographical Studies. № 3. S. 127-142.

Marcinkiewicz-Kaczmarczyk, A. 2016. Członkinie Ochotniczej Legii Kobiet — ich postawy i zasługi w latach 1918-1922. Polish Biographical Studies. № 4. S. 7-23.

Mroczko, M. 2013. Eugeniusza Romera zabiegi o odbudowę i bezpieczny kształt granic niepodległej Polski. Polish Biographical Studies. № 1. S. 35-56.

Mysiakowska-Muszyńska, J. 2017. Kobiety niepokorne, czyli o liderkach Narodowej Organizacji Kobiet. Szkic do portretu zbiorowego działaczek Narodowej Demokracji (19191929). Polish Biographical Studies. № 5. S. 7-32.

Olejnik, K. 2013. Trudności związane z pisaniem biografii wybitnych postaci z kręgów wojskowych. Polish Biographical Studies. № 1. S. 27-35.

Paczos, S. 2015. Przyczynek do charakterystyki koncepcji gospodarczych Jana Bobrzyńskiego. Polish Biographical Studies. № 3. S. 33-56.

Potkański, W. 2015. Jan Wacław Machajski (27 XII 1866-19 II 1926). Polish Biographical Studies. № 3. S. 11-30.

Rembacka, K. 2013. «Dodatkowy dzień tygodnia» Leonarda Borkowicza. Polish Biographical Studies. № 1. S. 137-148.

Rzepa, T. 2013. O biografii jako przedmiocie i rezultacie badań psychospołecznych. Polish Biographical Studies. № 1. S. 11-26.

Semczyszyn, M. 2014. Icchak Cukierman, Aba Kowner i Eliezer Lidowski — organizatorzy powojennej emigracji żydowskiej do Palestyny. Polish Biographical Studies. № 2. S. 93-112.

Siedziako, M. 2013. Szczecińscy katolicy po Październiku '56. Polish Biographical Studies. № 1. S. 149-172.

Sikorski, T. 2013. «Akademik» — pismo i środowisko (1945-1947). Przyczynek do historii niezależnego ruchu studenckiego po zakończeniu II wojny światowe. Polish Biographical Studies. № 1. S. 97-118. 
Szumiło, M. 2014. Roman Zambrowski. Biografia komunisty — źródła i metodologia badań. Polish Biographical Studies. № 2. S. 49-63.

Turek, W. 2015. Przeobrażenia społeczne w Gdyni po 1939 roku w świetle «biegu życia» działaczy i sympatyków obozu narodowego. Polish Biographical Studies. № 3. S. 73-98.

Turek, W. 2013. Zygmunt Berezowski (1891-1979). Polish Biographical Studies. № 1. S. 191-296.

Tyszkiewicz, A. 2016. «Za obronę własnych przekonań» — działalność społecznopolityczna Adama Pleśnara (1935-2013) do 1977 roku. Polish Biographical Studies. № 4. S. 99-116.

Wątor, A. 2013. Leon Tomasz Reutt (1884-1939). Szkic do portretu prezydenta miasta Drohobycza. Polish Biographical Studies. № 1. S. 83-96.

Wiertelak, P. 2016. Portret Wandy Półtawskiej na tle zawiłości społeczno-obyczajowych XX wieku. Polish Biographical Studies. № 4. S. 117-141.

Wojdyło, W. 2014. Biografie intelektualne twórców i kreatorów endeckiej myśli politycznej w Drugiej Rzeczypospolitej. Rekonesans bibliograficzny. Polish Biographical Studies. № 2. S. 63-76.

Yasui, M. 2013. Leon Reich (1879-1929). Sylwetka przywódcy syjonistów w Galicji Wschodniej. Polish Biographical Studies. № 1. S. 57-83.

Kotliarova, T. V. 2016. Vitchyzniana biohrafika, biohrafistyka ta biobibliohrafiia v roky nezalezhnosti Ukrainy. Dvanadtsiati Biohrafichni chytannia [Domestic Biography, Biography and Biobibliography during the Years of Independence of Ukraine]. Ukrainska biohrafistyka. Vyp. 13. S. 286-298. [in Ukranian]

Stambol, I. 2019. Teoretychni problemy polskoi biohrafistyky na storinkakh vydannia «Polish Biographical Studies» [Theoretical Problems of Polish Biography on the Pages of the Publication «Polish Biographical Studies»]. Materialy Mizhnarodnoi naukovoi konferentsii «Biblioteka. Nauka. komunikatsiia: aktualni tendentsii u tsyfrovu epokhu». Kyiv: NBUV. URL: http://conference.nbuv.gov.ua/report/view/id/861 [in Ukranian]

Tymchenko, V. M. 2008. Porivnialna kharakterystyka polskoi ta avstriiskoi biohrafichnoi dovidkovoi literatury [Comparative Characteristics of Polish and Austrian Biographical References]. Ukrainska biohrafistyka. Vyp. 4. S. 297-305. [in Ukranian]

Shapoval, Yu. I. 2018. Mykhailo Hrushevskyi. Ya sam pryishov do polityky cherez istoriiu [Mykhailo Hrushevsky: "I Came to Politics Through History Myself...»]. Kyiv: Parlamentske vyd-vo.

Cichocka, M. 2016. Zdeterminowani. Fragmenty życiorysów trzech rządców Kurii Gorzowskiej (1945-1956) [Determined. Fragments of Three Biographies of the Rulers of the Curia Gorzowska (1945-1956)]. Polish Biographical Studies. № 4. S. 65-98. [in Polish]

Drozdowski, M. 2014. «Eugeniusz Kwiatkowski o Szczecinie i Pomorzu Zachodnim» [«Eugeniusz Kwiatkowski about Szczecin and Western Pomerania»]. Polish Biographical Studies. № 2. S. 131-146. [in Polish]

Eisler, J. 2014. Dlaczego nie lubimy biografii dotyczących osób z czasów PRL? [Why do Not we Like Biographies about People from the PRL Times?]. Polish Biographical Studies. № 2. S. 39-48. [in Polish].

Grysińska-Jarmuła, K. 2016. Tendencje rozwojowe polskiej biografistyki od konca XIX do poczatkow XXI wieku [Development Trends of Polish Biography from the End of the $19^{\text {th }}$ 
Century to the Beginning of the 21st Century]. Ukrainska biohrafistyka. Vyp. 13. S. 51-74. [in Polish and Ukranian]

Indraszczyk, A. 2013. Adam Bień 1899-1998. Szkic biograficzny [Adam Bien 1899-1998. Biographical Sketch]. Polish Biographical Studies. № 1. S. 177-190. [in Polish]

Konopczyńska-Tota, E. 2014. Filolog w archiwum. W poszukiwaniu źródeł do biografii Jakuba Laskiera [Philologist in the Archive. In the Search for Sources for a Biography of James Laskier]. Polish Biographical Studies. № 2. S. 113-130. [in Polish]

Krasucki, E. 2014. Dyskusje polskich historyków (krajowych) wokół biografistyki między «odwilżą» a upadkiem PRL [Discussions of Polish Historians (national) Around Biography — Between the «Thaw» and the Fall of the PRL]. Polish Biographical Studies. № 2. S. 11-39. [in Polish]

Król, J. 2015. Janina Parafiniuk-Soińska (1922-2012): szczecińska pedagog i uczona [Janina Parafiniuk-Soińska (1922-2012): Szczecin Educator and Scholar]. Polish Biographical Studies. № 3. S. 143-158. [in Polish]

Łętocha, R. 2015. Fundamenty ideowe myśli społeczno-gospodarczej i politycznej ks. Jana Piwowarczyka [Ideological Foundations of Socio-Economic and political Thought of Jan Piwowarczyk]. Polish Biographical Studies. № 3. S. 57-72. [in Polish]

Łętocha, R. 2016. Tadeusz Łopuszański: pedagog, wychowawca, polityk [Tadeush Lopuszanski: Teacher, Educator, Politician]. Polish Biographical Studies. № 4. S. 51-63. [in Polish]

Madejski, J. 2014. Portret, słownik, sylwa... Biografistyka (literacka) na przełomie XX i XXI wieku [Portrait, Dictionary, Sylwa ... Biography (Literary) at the Turn of the $20^{\text {th }}$ and $21^{\text {st }}$ Centuries]. Polish Biographical Studies. № 2. S. 77-92. [in Polish]

Magiera, E. 2015. Bolesław Wojciech Sadaj (1908-1997) jako twórca szczecińskiej pedagogiki [Bolesław Wojciech Sadaj (1908-1997) as a Creator of Szczecin Pedagogy]. Polish Biographical Studies. № 3. S. 127-142. [in Polish]

Marcinkiewicz-Kaczmarczyk, A. 2016. Członkinie Ochotniczej Legii Kobiet — ich postawy i zasługi w latach 1918-1922 [Members of the Volunteer Legion of Women - Their Attitudes and Merits in 1918-1922]. Polish Biographical Studies. № 4. S. 7-23. [in Polish]

Mroczko, M. 2013. Eugeniusza Romera zabiegi o odbudowę i bezpieczny kształt granic niepodległej Polski [Eugeniusz Romer's Efforts to Rebuild and Secure the Shape of the Borders of Independent Poland]. Polish Biographical Studies. № 1. S. 35-56. [In Polish]

Mysiakowska-Muszyńska, J. 2017. Kobiety niepokorne, czyli o liderkach Narodowej Organizacji Kobiet. Szkic do portretu zbiorowego działaczek Narodowej Demokracji (19191929) [Defiant Women, or the Leaders of the National Women's Organization. Sketch for the Collective Portrait of National Democracy Activists (1919-1929)]. Polish Biographical Studies. № 5. S. 7-32. [in Polish]

Olejnik, K. 2013. Trudności związane z pisaniem biografii wybitnych postaci z kręgów wojskowych [Difficulties Associated with Writing Biographies of Eminent Figures from Military Circles]. Polish Biographical Studies. № 1. S. 27-35. [in Polish]

Paczos, S. 2015. Przyczynek do charakterystyki koncepcji gospodarczych Jana Bobrzyńskiego [Contribution to the Economic Characteristics of the Concept of John Bobrzyńskiego]. Polish Biographical Studies. № 3. S. 33-56. [in Polish]

Potkański, W. 2015. Jan Wacław Machajski (27 XII 1866-19 II 1926) [Jan Vaclav Machajski (27 XII 1866-19 II 1926)]. Polish Biographical Studies. № 3. S. 11-30. [in Polish] 
Rembacka, K. 2013. «Dodatkowy dzień tygodnia» Leonarda Borkowicza [«An Additional Day of the Week» by Leonardo Borkowicz]. Polish Biographical Studies. № 1. S. 137-148. [in Polish]

Rzepa, T. 2013. O biografii jako przedmiocie i rezultacie badań psychospołecznych [About Biography as a Subject and the Result of Psychosocial Research]. Polish Biographical Studies. № 1. S. 11-26. [in Polish]

Semczyszyn, M. 2014. Icchak Cukierman, Aba Kowner i Eliezer Lidowski - organizatorzy powojennej emigracji żydowskiej do Palestyny [Icchak Cukierman, Aba Kowner and Eliezer Lidowski - Organizers of Post-War Jewish Emigration to Palestine]. Polish Biographical Studies. № 2. S. 93-112. [in Polish]

Siedziako, M. 2013. Szczecińscy katolicy po Październiku '56 [Szczecin Catholics after October '56]. Polish Biographical Studies. № 1. S. 149-172. [in Polish]

Sikorski, T. 2013. «Akademik» — pismo i środowisko (1945-1947). Przyczynek do historii niezależnego ruchu studenckiego po zakończeniu II wojny światowe [«Akademik» — Magazine and Environment (1945-1947). A Contribution to the History of the Independent Student Movement after the End of World War II]. Polish Biographical Studies. № 1. S. 97-118. [in Polish]

Szumiło, M. 2014. Roman Zambrowski. Biografia komunisty — źródła i metodologia badań [Roman Zambrowski. Communist Biography — Sources and Research Methodology]. Polish Biographical Studies. № 2. S. 49-63. [in Polish]

Turek, W. 2015. Przeobrażenia społeczne w Gdyni po 1939 roku w świetle «biegu życia» działaczy i sympatyków obozu narodowego [Social Transformations in Gdynia after 1939 in the Light of the "Course of Life» of Activists and Supporters of the National Camp]. Polish Biographical Studies. № 3. S. 73-98. [In Polish]

Turek, W. 2013. Zygmunt Berezowski (1891-1979) [Zygmunt Berezovski (1891-1979)]. Polish Biographical Studies. № 1. S. 191-296. [in Polish]

Tyszkiewicz, A. 2016. «Za obronę własnych przekonań» — działalność społecznopolityczna Adama Pleśnara (1935-2013) do 1977 roku [«For the Defense of One's Own Beliefs» - Social and Political Activity of Adam Pleśnar (1935-2013) until 1977]. Polish Biographical Studies. № 4. S. 99-116. [in Polish]

Wątor, A. 2013. Leon Tomasz Reutt (1884-1939). Szkic do portretu prezydenta miasta Drohobycza [Leon Tomasz Reutt (1884-1939). Sketch for the Portrait of the President of Drohobych]. Polish Biographical Studies. № 1. S. 83-96. [in Polish]

Wiertelak, P. 2016. Portret Wandy Półtawskiej na tle zawiłości społeczno-obyczajowych XX wieku [A Portrait of Wanda Półtawska against the Background of Social and Moral Complexities of the $20^{\text {th }}$ Century]. Polish Biographical Studies. № 4. S. 117-141. [in Polish]

Wojdyło, W. 2014. Biografie intelektualne twórców i kreatorów endeckiej myśli politycznej w Drugiej Rzeczypospolitej. Rekonesans bibliograficzny [Intellectual Biographies of the Creators of Political Thought in the Second Polish Republic. Bibliographic Exploration]. Polish Biographical Studies. № 2. S. 63-76. [in Polish]

Yasui, M. 2013. Leon Reich (1879-1929). Sylwetka przywódcy syjonistów w Galicji Wschodniej [Profile of the Zionist Leader in Eastern Galicia]. Polish Biographical Studies. № 1. S. 57-83. [in Polish] 


\section{ВІДОМОСТІ ПРО АВТОРІВ}

Бортніков Валерій Іванович — доктор політичних наук, професор кафедри політології та державного управління Волинського національного університету імені Лесі Українки.

Бортнікова Алла Василівна - доктор політичних наук, доцент кафедри всесвітньої історії та філософії Волинського національного університету імені Лесі Українки.

Вісла Рафал - доктор економічних наук, професор кафедри економіки та інновацій Ягеллонського університету, м. Краків (Польща).

Грубінко Андрій Васильович - доктор історичних наук, професор, професор кафедри теорії та історії держави і права юридичного факультету Західноукраїнського національного університету Класичний університет Тернополя.

Жам Олена Михайлівна - кандидат історичних наук, професор Української технологічної академії, провідний науковий співробітник Музею хліба Національного історико-етнографічного заповідника «Переяслав».

Захарченко Петро Павлович - кандидат історичних наук, доктор юридичних наук, професор, професор кафедри теорії історії права та держави Інституту права Київського національного університету імені Тараса Шевченка.

Зуляк Іван Степанович - доктор історичних наук, професор кафедри істоpiї України, археології та спеціальних галузей історичних наук Тернопільського національного педагогічного університету імені Володимира Гнатюка.

Казьмирчук Марія Григорівна - доктор історичних наук, доцент, доцент кафедри етнології та краєзнавства історичного факультету Київського національного університету імені Тараса Шевченка.

Карасевич Анатолій Олександрович — кандидат філософських наук, професор кафедри філософії та суспільних дисциплін, декан історичного факультету Уманського державного педагогічного університету імені Павла Тичини.

Карпічков Віталій Олександрович — кандидат юридичних наук, асистент кафедри історії права та держави Інституту права Київського національного університету імені Тараса Шевченка.

Кліш Андрій Богданович - доктор історичних наук, доцент кафедри історії України, археології та спеціальних галузей історичних наук Тернопільського національного педагогічного університету імені Володимира Гнатюка.

Комарніцький Олександр Борисович - доктор історичних наук, профеcop, професор кафедри історії України Кам'янець-Подільського національного університету імені Івана Огієнка.

Коросташова Ірина Миколаївна — кандидат юридичних наук, доцент, доцент кафедри Навчального наукового інституту права та міжнародно-правових відносин Університету митної справи та фінансів (м. Дніпро, Україна). 
Коцъюбанська Ольга Олександрівна - кандидат історичних наук, доцент, доцент Національного університету харчових технологій (Київ, Україна).

Кудряченко Андрій Іванович - доктор історичних наук, професор, член-кореспондент НАН України, директор Державної установи «Інститут всесвітньої історії Національної академії наук України».

Куницький Михайло Петрович - доктор історичних наук, доцент кафедри всесвітньої історії та філософії факультету історії, політології та національної безпеки Волинського національного університету імені Лесі Українки.

Левицька Надія Миколаївна - доктор історичних наук, професор, професор Національного університету харчових технологій (Київ, Україна).

Мірошниченко Марія Іванівна - доктор юридичних наук, завідувач кафедри історії права та держави Інституту права Київського національного університету імені Тараса Шевченка.

Молдавський Роман Леонідович — кандидат історичних наук, доцент, доцент кафедри джерелознавства, історіографії та спеціальних історичних дисциплін історичного факультету Запорізького національного університету.

Палієнко Сергій Володимирович - кандидат історичних наук, докторант Київського національного університету імені Тараса Шевченка.

Пивоваренко Олена Андрївна - кандидат історичних наук, доцент кафедри гуманітарних дисциплін Навчально-наукового інженерно-технічного інституту ім. акад. І. С. Гулого Національного університету харчових технологій.

Потєхін Олександр Володимирович — доктор історичних наук, професор кафедри всесвітньої історії, міжнародних відносин та методики навчання історичних дисциплін навчально-наукового інституту історії та філософії Сумського державного педагогічного університету імені А. С. Макаренка.

Разиграєв Олег Володимирович - кандидат історичних наук, доцент кафедри всесвітньої історії та філософії факультету історії, політології та національної безпеки Волинського національного університету імені Лесі Українки.

Рогожа Марія Миколаївна - кандидат історичних наук, доцент кафедри історії України Уманського державного педагогічного університету імені Павла Тичини.

Романюк Неля Йосипівна - доктор історичних наук, професор кафедри суспільних наук факультету права, публічного управління та національної безпеки Житомирського національного агроекологічного університету.

Рудянин Іван Петрович - кандидат історичних наук, доцент кафедри історії України та археології факультету історії, політології та національної безпеки Волинського національного університету імені Лесі Українки.

Соляр Ігор Ярославович - доктор історичних наук, старший науковий співробітник директор Інституту українознавства ім. І. Крип’якевича НАН 
України; професор кафедри гуманітарних наук Національної академії сухопутних військ імені гетьмана Петра Сагайдачного.

Стамбол Ігор Іванович - кандидат історичних наук, доцент кафедри бібліотекознавства та інформології Інституту журналістики Київського університету імені Бориса Грінченка.

Степанова Оксана Валерї̈вна - аспірант кафедри історії України історико-юридичного факультету Ніжинського державного університету імені Миколи Гоголя.

Тарасюк Марина Юріївна - аспірант кафедри історії факультету соціології і права Національного технічного університету України «Київський політехнічний інститут імені Ігоря Сікорського».

Харук Андрій Іванович — доктор історичних наук, професор, завідувач кафедри гуманітарних наук Національної академії сухопутних військ імені гетьмана Петра Сагайдачного.

Чуткий Андрій Іванович - доктор історичних наук, доцент, доцент кафедри давньої та нової історії України історичного факультету Київського національного університету імені Тараса Шевченка.

Шугальова Інна Михайлівна - кандидат історичних наук, доцент, доцент кафедри історії України історичного факультету Запорізького національного університету. 


\section{INFORMATION ABOUT AUTHORS}

Bortnikov Valerii - doctor of political sciences, professor of the Department of Political Science and Public Administration, Faculty of History, Political Science and National Security, Lesya Ukrainka Volyn National University.

Bortnikova Alla - doctor of political sciences, associate professor of the Department of World History and Philosophy, Faculty of History, Political Science and National Security, Lesya Ukrainka Volyn National University.

Wisła Rafat - doctor habilitatus in economics, professor of the кафедри економіки та інновацій Ягеллонського університету, Faculty of Management and Social Communication, Institute of Economics, Finance and Management, Jagiellonian University in Kraków (Poland).

Hrubinko Andrii - doctor of historical sciences, professor, professor of the Department of Theory and History of State and Law, Faculty of Law, West Ukrainian National University (Ternopil).

Zham Olena - candidate of historical sciences, professor of the Ukrainian Technological Academy, leading researcher of the Museum of Bread of Natsional Historical-Ethnographic Preserve «Pereyaslav».

Zakharchenko Petro - candidate of historical sciences, doctor of legal sciences, professor of the Department of Theory and History of State and Law, Institute of Law, Taras Shevchenko National University of Kyiv.

Zulyak Ivan - doctor of legal sciences, professor of the Department of History of Ukraine, Archaeoloty and Special Branches of Historical Science, Ternopil Volodymyr Hnatiuk National Pedagogical University.

Kazmyrchuk Mariia - doctor of historical sciences, docent, associate professor of Department of Ethnology and Local History, Faculty of History, Taras Shevchenko National University of Kyiv.

Karasevych Anaoliy - candidate of philosophical sciences, professor of the chair of Philosophy and Social Sciences, dean of the Historical Department at Pavlo Tychyna Uman State Pedagogical University

Karpichkov Vitalii - candidate of legal sciences, assiatant of the Department of Theory and History of State and Law, Institute of Law, Taras Shevchenko National University of Kyiv.

Klish Andriy - doctor of historical sciences, professor, associate professor of the Department of History of Ukraine, Archaeoloty and Special Branches of Historical Science, Ternopil Volodymyr Hnatiuk National Pedagogical University.

Komarnitskyi Oleksandr - doctor of historical sciences, professor, professor of the Department of History of Ukraine, Kamianets-Podilskyi National Ivan Ohiienko University. 
Korostashova Iryna - candidate of legal sciences, docent, associate professor of the Educational and Research Institute of Law, University of Customs and Finance (Dnipro, Ukraine).

Kotsuibanska Olga - candidate of historical sciences, associate professor, associate professor of National University of food Technology (Kyiv, Ukraine).

Kudriachenko Andrii - doctor of historical sciences, professor, corresponding Member of National Academy of Sciences of Ukraine, head of The State Institution "Institute of World History of the National Academy of Sciences of Ukraine»..

Kunytskyy Mykhailo - doctor of historical sciences, associate professor of the Department of World History and Philosophy, Faculty of History, Political Science and National Security, Lesya Ukrainka Volyn National University.

Levitska Nadya - doctor of historical sciences, professor, professor of National University of food Technology.

Miroshnichenko Mariia - doctor of legal sciences, head of the Department of Theory and History of State and Law, Institute of Law, Taras Shevchenko National University of Kyiv.

Moldavskij Roman - candidate of historical sciences, docent, associate professor of the Department of Source Studies, Historiography and Special Historical Disciplines, Faculty of History, Zaporizhzhia National University.

Paliienko Sergii - candidate of historical sciences, doctoral candidate, Taras Shevchenko National University of Kyiv.

Pyvovarenko Olena - candidate of historical sciences, associate professor of the Department of Humanities, Educational and Scientific Institute of Technical Engineering by name of academician I. S. Hulyi, National University of Food Technologies.

Potiekhin Oleksandr - doctor of historical sciences, professor, professor of Department of World History, International Relations and Methods of Teaching Historical Disciplines, Educational and Scientific Institute of History and Philosophy, Sumy State Pedagogical University named by A. S. Makarenko.

Razyhrayev Oleh - candidate of historical sciences, associate professor of the Department of the Department of World History and Philosophy, Faculty of History, Political Science and National Security, Lesya Ukrainka Volyn National University.

Rohozha Mariya - candidate of historical sciences, associate professor of the Department of the History of Ukraine, Pavlo Tychyna Uman State Pedagogical University.

Romaniuk Nelia - doctor of historical sciences, professor of Department of Department of Social Science, Faculty of Economic Security, Public Administration and Management, Zhytomyr National Agroecological University. 
Rudyanin Ivan - candidate of historical sciences, associate professor of the Department of History of Ukraine and Archaeology, Faculty of History, Political Science and National Security, Lesya Ukrainka Volyn National University

Soliar Ihor - doctor of historical sciences, senior research officer, director of Ivan Krypiakevych Institute of Ukrainian Studies of the National Academy of Sciences of Ukraine; professor at the Department of humanities, Hetman Petro Sahaidachnyi National Army Academy.

Stambol Ihor - candidate of historical sciences, associate professor of the Department of Library Studies and Informology, Institute of Journalism, Kyiv Boris Grinchenko University.

Stepanova Oksana - PhD student of the Department of History, Faculty of History and Law, Nizhyn Gogol State University.

Tarasiuk Maryna - PhD student of the Department of History, Faculty of Sociology and Law, National Technical University of Ukraine «Ihor Sikorsky Kyiv Polytechnic Institute».

Kharuk Andrii - doctor of historical sciences, professor, head of a Department of humanities, Hetman Petro Sahaidachnyi National Army Academy.

Chutkyi Andrii - doctor of historical sciences, docent, associate professor, of the Department of Ancient and Modern History of Ukraine, Faculty of History, Taras Shevchenko National University of Kyiv.

Shugalyova Inna - candidate of historical sciences, docent, associate professor of the Department of History of Ukraine, Faculty of History, Zaporizhzhia National University. 